\title{
MODEL PEMBELAJARAN TALKING STICK SEBAGAI PENDUKUNG PENGUASAAN ENGLISH VOCABULARY PADA ANAK USIA DINI
}

\author{
Oleh \\ I Putu Andre Suhardiana \\ Institut Hindu Dharma Negeri Denpasar \\ Email: putuandresuhardiana@gmail.com
}

\begin{abstract}
Language is a developmental aspect which is important to be stimulated from an early age. Language development in children has a dynamic rhythm. There is numerous speech that seems common and consistent in the language of children. Fortunately, this phenomenon does not automatically close the gaps of diversity in the children's classes. Thus, the method of developing language skills especially English in children must be based on awareness of their own level of development. In developing language skills, the mastery of vocabulary by children determines the dominant ability to communicate, so this should be given special attention by educators. Answering the challenge of mastering the English vocabulary in early childhood, this paper explores in depth about the Talking Stick Learning Model which tends to be reserved for children at a relatively early age. Their first interaction with English will in some way affect their wishes ahead to learn more about this International language. Talking Stick Learning Model projects teachers not to dominate the learning process. This method of learning requires the help of a stick and for the child holding the stick, in turn, must answer the questions of the teacher that have thoroughly studied a discussion. In addition to training children to speak, this model will create a fun atmosphere for learning and train students to participate actively and creatively.
\end{abstract}

\section{Keywords: Talking Stick Learning Model, English Vocabulary, Early Childhood}

\begin{abstract}
Abstrak
Bahasa adalah aspek perkembangan yang penting untuk distimulus sejak usia dini. Perkembangan bahasa pada anak memiliki irama yang dinamis. Terdapat ujaran yang terkesan umum dan konsisten pada bahasa anak-anak. Untungnya, fenomena ini tidak secara otomatis menutup celah-celah munculnya keberagaman pada kelas-kelas anak. Dengan demikian, metode dalam mengembangkan kemampuan berbahasa, terlebih bahasa Inggris, pada anak mesti didasarkan atas kesadaran mengenai tingkat perkembangan mereka masing-masing. Dalam mengembangkan kemampuan berbahasa, penguasaan kosakata oleh anak menentukan secara dominan kemampuannya dalam berkomunikasi, sehingga hal ini sebaiknya diberikan atensi khusus oleh pendidik. Menjawab tantangan penguasaan kosakata bahasa Inggris pada anak usia dini, tulisan ini mengupas secara mendalam tentang Model Pembelajaran Talking Stick yang cenderung diperuntukkan bagi anak-anak pada usia relatif dini. Interaksi pertama mereka dengan bahasa Inggris akan sedikit banyak mempengaruhi keinginan mereka ke depan mempelajari lebih jauh bahasa Internasional ini. Model Pembelajaran Talking Stick memproyeksikan guru untuk tidak mendominasi proses pembelajaran. Bantuan tongkat diperlukan dalam metode pembelajaran ini dan bagi anak yang memegang tongkat pada gilirannya mesti menjawab pertanyaan dari guru setelah tuntas mempelajari suatu bahasan. Di
\end{abstract}

PRATAMA WIDYA, VOL. 3, NO. 1, 2018 
samping melatih anak berbicara, model ini akan menciptakan suasana menyenangkan dalam pembelajaran serta melatih siswa untuk berpartisipasi aktif serta kreatif.

\section{Kata Kunci: Model Pembelajaran Talking Stick, English Vocabulary, Anak Usia Dini}

\section{PENDAHULUAN}

Bahasa Inggris pada masa sekarang ini tidak boleh dipandang sebelah mata. Melihat fenomena begitu pentingnya bahasa Inggris, banyak orang tua yang memiliki hasrat mengajarkan anaknya bahasa Inggris sejak usia dini. Mengajarkan anak usia dini memang terkesan tidak mudah, tidak hanya bahasa Inggris saja, melainkan banyak hal lainnya. Dalam mengajarkan bahasa Inggris pada anak usia dini, cara yang sangat berbeda tentu perlu untuk diaplikasikan jika dibandingkan pembelajaran yang diperuntukkan pada remaja atau dewasa. Anak-anak hanyalah bisa diajarkan dasarnya saja pada usia dini, bahkan mereka diajarkan dengan cara yang mereka ketahui yaitu bermain, akan tetapi tidak hanya sekadar bermain. Bermain yang dimaksudkan adalah bermain dengan arahan-arahan tertentu. Anak-anak tentunya bisa belajar banyak hal melalui bermain yang diarahkan. Kita perlu mengetahui bahwa pada saat bermain, keadaan otak anak ada dalam situasi tenang dikarenakan ia merasa senang dan ceria. Ilmu tentunya bisa masuk dan tertanam dengan mudah dan baik dalam keadaan ini. Penekanan yang penting dalam hal ini adalah, anak usia dini lebih baik diajarkan dasar-dasarnya saja. Sama halnya dalam pengajaran bahasa Inggris pada anak usia dini. Yang perlu diajarkan yaitu hal-hal yang sangat mendasar terlebih dahulu terkait kosakata (Vocabulary), misalnya dengan menggunakan huruf-huruf, angka-angka serta gambar-gambar yang menarik.

Aktivitas belajar yang dilakukan di usia dini dan usia dewasa menghasilkan luaran yang berbeda. Pada kenyataannya, individu lebih mudah menyerap pelajaran di usia dini daripada mempelajarinya ketika tua. Hal ini juga berlaku dalam mempelajari bahasa Inggris. Mengapa bahasa Inggris perlu dipelajari sejak dini? Pertama, anak-anak memiliki masa emas dalam belajar yang dikenal populer dengan istilah golden age, yaitu usia 6-12 tahun, yang memungkinkannya anak belajar bahasa secara cepat. Mereka masih memiliki otak yang elastis sehingga dapat menyerap materi pelajaran dengan mudah, terlebih jika materi yang mereka pelajari berkaitan dengan bahasa yang dipergunakan sebagai sarana komunikasi. Kedua, anak-anak memiliki memori otak yang begitu luar biasa. Mereka mudah menyerap suatu materi dengan daya ingatnya yang tinggi dan mengingatnya dalam jangka waktu yang lama. Ketiga, anak-anak mempunyai rasa keingintahuan yang sangat besar. Mereka suka bertanya, melakukan eksplorasi terhadap sesuatu, dan mencari serta menemukan cara-cara baru untuk dipraktikkan. Mereka lebih mudah mempelajari bahasa Inggris dikarenakan hal ini, dengan cara yang menyenangkan serta tanpa terkesan sedang belajar. 
Menelisik lebih jauh, manfaat anak mempelajari bahasa Inggris sejak dini adalah agar bahasa Inggris tidak membuat anak merasa asing. Bahasa Inggris tidak akan lagi menjadi momok yang menakutkan dikarenakan telah dipelajari sejak kecil. Bahkan, mereka akan merasa lebih akrab terhadap bahasa Inggris, contohnya ketika mereka bisa mendengarkannya setiap kali menonton film kartun anak dari channel luar negeri. Di tengah krisis tontonan televisi bermutu untuk anak saat ini, rasanya menonton film kartun luar negeri atau acara semacam discovery channel menjadi alternatif tontonan yang sehat dan menyenangkan. Kedua, ada anggapan bahwa anak yang menguasai bahasa Inggris mempunyai skill lebih yang tentunya akan membuatnya mudah menjalani masa sekolah yang menyenangkan. Ini karena skill bahasa Inggris juga diperhitungkan. Selanjutnya, gerbang pengetahuan akan semakin terbuka lebar. Bahasa Inggris, seperti diketahui, merupakan bahasa pengetahuan, bahasa pengantar keilmuan terkini, baik secara online ataupun offline. Dengan berbekal penguasaan bahasa Inggris, seorang anak bisa melakukan akses lebih banyak mengenai informasi dan pengetahuan dari luar negeri yang memudahkannya lebih update pada perkembangan keilmuan terbaru. Kemudian, belajar bahasa Inggris sejak dini akan mempersiapkannya untuk menghadapi masa depan dengan lebih matang. Bahasa Inggris merupakan bahasa global yang digunakan oleh hampir sebagian besar penduduk dunia, hampir sebagian situasi, serta hampir sebagian profesi. Bahasa Inggris adalah bahasa komunikasi, bahasa pengetahuan, dan bahasa bisnis. Jika anak ingin melanjutkan pendidikan di luar negeri, penguasaan bahasa Inggris semenjak dini tentulah akan sangat menguntungkan.

\section{Melihat}

kebermanfaatan

pembelajaran Bahasa Inggris terutama penguasaan vocabulary untuk anak usia dini, sejatinya, pendidik dapat memanfaatkan model pembelajaran talking stick untuk memperkenalkan bahasa Internasional ini. Dalam banyak penelitian yang telah dilakukan, talking stick merupakan salah satu dari sekian banyak model pembelajaran kooperatif yang memiliki peran sentral dalam menciptakan keaktifan siswa dalam proses belajar mengajar. Seperti yang dikemukakan oleh Suprijono (2015: 128), bahwa model pembelajaran kooperatif tipe talking stick merupakan pembelajaran yang dapat mendorong siswa untuk berani mengemukakan pendapat. Terlebih lagi, Kurniasih (2015: 82), menyatakan bahwa model pembelajaran talking stick adalah satu dari sekian banyak model pembelajaran kooperatif. Aplikasi dari model pembelajaran ini dilakukan dengan bantuan tongkat. Tongkat dijadikan sebagai penanda giliran untuk mengeluarkan pendapat atau menjawab pertanyaan dari guru setelah anakanak mempelajari suatu bahan. Sepakat dengan pendapat Kurniasih, Huda (2014: 224) menyatakan bahwa talking stick merupakanmodel pembelajarankelompok dengan bantuan tongkat. Kelompok yang memegang tongkat terlebih dahulu wajib menjawab pertanyaan dari guru setelah 
mereka mempelajari bahan secara tuntas. Selanjutnya, Carol Locust dalam Huda (2014: 224) menyatakan bahwa:

The talking stick has been used for centuries by many indian tribes as a mean of just and impartial hearing. The talking stick was used commonly in council circles in deciding who had the right to speak. When maters of great concern would come before the council, the leading elder would hold the talking stick, and begins the discussion., He would hold out the talking stick when he would finish what he had to say, and whoever would speak after him would take it. In this manner, the stick would be passed from one individual to another until all who wanted to speak had done so. The stick was then passed back to the elder for safe keeping.

Jadi, talking stick (tongkat berbicara) pada awalnya adalah model yang dipergunakan oleh suku Indian (penduduk asli Amerika) dalam rangka mengajak semua orang berbicara atau menyampaikan pendapat dalam suatu forum (pertemuan antar suku). Hingga saat ini, model itu sudah digunakan sebagai model pembelajaran di ruang kelas. Sepertin namanya, talking stick merupakan model pembelajaran yang dipergunakan dalam kelompok dengan bantuan tongkat. Berdasarkan pendapat para ahli di atas, peneliti memberikan kesimpulan bahwa model pembelajaran kooperatif tipe talking stick adalah pembelajaran yang menggunakan kelompok-kelompok dimana guru menggunakan tongkat sebagai media agar siswa terdorong untuk berani mengemukakan pendapat serta menumbuhkan rasa percaya diri siswa.

Menurut pendapat Kurniasih (2015: 83), model pembelajaran talking stick memiliki beberapa kelebihan, yaitu: dapat menguji kesiapan siswa dalam penguasaan materi pelajaran, dapat melatih siswa dalam membaca dan memahami dengan cepat materi yang telah disampaikan, dapat membuat siswa menjadi lebih giat belajar karena mereka tidak pernah tahu tongkat akan sampai pada gilirannya. Sejalan dengan Kurniasih, Suprijono (2009: 110), mengungkapkan kelebihan pembelajaran kooperatif tipe talking stick, diantaranya model talking stick dapat menguji kesiapan siswa, dapat melatih siswa membaca serta memahami materi dengan cepat, dapat memacu siswa agar lebih giat belajar, dapat membuat siswa berani mengemukakan pendapat. Berdasarkan pendapat para ahli di atas, maka dapat disimpulkan bahwa kelebihan talking stick adalah menguji kesiapan siswa, melatih keterampilan mereka dalam membaca, memahami materi pelajaran dengan cepat, dan siswa berani mengemukakan pendapat.

\section{PEMBAHASAN}

\subsection{Konsep Anak Usia Dini}

Anak merupakan aset bangsa yang paling berharga. Sehingga anak 
adalah penerus regenerasi bangsa itu sendiri. Atensi yang mendalam mesti diberikan dalam perkembangannya, guna memperoleh anak yang memiliki sumber daya manusia yang kompeten serta unggul dan dapat bersaing. Dengan demikian, dalam perjalanannya, mengasuh anak tidak hanya merawat dan memenuhi segala macam kebutuhan fisiknya, melainkan juga mempersiapkan mereka agar dapat hidup bermasyarakat. Proses ini bisa dikerjakan di rumah melalui interaksi verbal maupun nonverbal. Mendidik anak sejak dini menjadi suatu kewajiban orang tua di rumah sejak dan kandungan hingga beranjak dewasa.

Masa usia dini adalah masa unik dalam kehidupan anak, karena merupakan masa pertumbuhan yang paling peka sekaligus paling sibuk. Kegiatan pembelajaran dalam hal ini mesti disesuaikan agar dapat memusatkan perhatian pada anak. Sebab anak merupakan dambaan bagi setiap orang tua dan generasi penerus bangsa. Pendidikan anak usia dini dilakukan mulai sejak lahir sampaidenganumurenam tahun. Berbagai penetian menyatakan bahwa masa kanakkanak adalah langkah awal menempatkan dasar-dasar perkembangan bahasa, fisik, sosial, seni, emosional, konsep din, serta nilai-nilai agama. Pandangan para ahli pendidikan tantang anak cenderung berubah dan waktu ke waktu dan berbeda satu sama lain sesuai dengan landasan teori yang digunakannya. Terdapat banyak konsep yang menyatakan bahwa anak adalah individu yang dibentuk oleh lingkungannya atau bahkan sudah membawa sifat-sifat tertentu sebagai bawaan sejak lahir. Terdapat pula beberapa pendapat lain yang menganggap anak sebagai miniatur orang dewasa, serta ada juga yang memandang anak sebagai individu yang berbeda.

Maria Montessori (dalam Hurlock, 1978:86) memberikan pernyataan bahwa anak pada usia usia 3-6 tahun sedang berada pada periode sensitif yang lebih dikenal dengan masa peka, yaitu suatu periode dimana suatu fungsi tertentu perlu dirangsang, diarahkan sehingga tidak terhambat perkembangannya. Periode sensitifitas anak pada usia ini adalah termasuk sensitif pada keteraturan dan kebersihan lingkungan, menjelajahi lingkungan sekitar dengan lidah dan serta tangan, sensitif untuk berjalan, sensitif pada objek-objek kecil dan terkesan detail, serta terhadap aspek-aspek sosial kehidupan. Pendapat lain dikemukakan oleh Erik H. Erikson (dalam Helms \& Turner, 1995:35), yang memandang periode usia 4-6 tahun sebagai fase sense of initiative. Perkembangan prakarsa anak pada periode ini mesti giat untuk didorong, seperti kemampuan dalam mengajukan pertanyaan-pertanyaan dari apa yang dilihat, didengar atau bahkan dirasakan. Terkadang hambatan muncul dari lingkungan anak yang menjadi penyebab sulit berkembangnya daya kreatif anak serta hal-hal yang produktif di bidang yang disenanginya. Orang tua yang cenderung memberikan pertolongan, nasihat, serta membantu menyelesaikan pekerjaan anak padahal mereka dapat melakukannya sendiri, menurut Erikson dapat membuat anak tidak mendapatkan kesempatan untuk berbuat kesalahan 
atau belajar dan kesalahan itu. Dalam periode ini, ketika anak terlalu banyak mendapatkan larangan dan teguran, maka mereka akan diliputi perasaan serba salah dan berdosa (guilty). Kelompok konstruktivisme yang dimotori oleh Jean Piaget dan Lev Vygotsky, berpendapat bahwa anak bersifat aktif dan memiliki kemampuan untuk membangun pengetahuannya.

\subsection{Peranan Bahasa dalam Perkembangan Anak Usia Dini}

Dalam kehidupan seharihari, manusia akan selalu memiliki keterikatan dengan bahasa. Bahasa dapat didefiniskan sebagai sistem tanda bunyi yang penyusunannya didasarkan atas kesepakatan bersama dan pada akhirnya dipergunakan sebagai alat komunikasi dalam rangka menjalankan interaksi sosial (Sunarto, 2008:24). Sedangkan dalam Metodik Berbahasa untuk Taman Kanak-Kanak (Departemen Pendidikan dan Kebudayaan, Jakarta, 2001), bahasa adalah alat dalam membantu membuat pernyataan pikiran serta perasaan kepada orang lain yang sekaligus juga memiliki fungsi untuk memahami pikiran serta perasaan orang lain. Dari dua pertanyaan tersebut di atas, dapat disimpulkan bahwa bahasa merupakan alat yang digunakan oleh individu untuk menyatakan suatu perasaan atau keinginan, permintaan, harapan, dan lain sebagainya kepada orang lain. Bahasa juga memberikan peranan yang bersifat penting dalam perkembangan anak. Dengan menggunakan bahasa, anak akan tumbuh serta berkembang menjadi manusia dewasa yang dapat bergaul di tengah-tengah masyarakat. Periode paling sensitif terhadap bahasa dalam kehidupan seseorang adalah antara 0-8 tahun. Sebelum masa sensitif ini berakhir, segala macam aspek dalam berbahasa mesti diperkenalkan kepada anak.

\subsection{Konsep Pembelajaran Bahasa inggris pada Anak Usia Dini}

Bagaimana mengajarkan bahasa inggris pada anak? Tentu tidak mudah jika yang dihadapi adalah anak usia dini. Bukan karena kursus maupun bakat yang menjadi penentu keberhasilan anak usia tersebut fasih berbahasa inggris. Tentunya diperlukan tips dan trik saat melakukannya. Dewasa ini, bahasa inggris menjadi wajib untuk dipelajari dan dikuasai karena merupakan bahasa internasional dan memiliki fungsi sebagai penghubung komunikasi secara global. Sehingga, dalam konteks ini, tidak sedikit para orang tua mulai memperkenalkan bahasa inggris pada anak mereka saat usia dini. Hal tersebut dikarenakan hampir semua sumber bacaan, tontonan, serta media komunikasi di sekitar kita dan anak yang menggunakan bahasa inggris.

Seorang guru bagi anak usia dini, sebelum melaksanakan kegiatan pembelajaran, mesti terlebih dahulu menuangkan fokus dan atensinya dalam mengenal karakteristik masing-masing anak yang dididik dan diajar agar program pembelajarannya sesuai dengan perkembangan dimensi anak-anak yang dalam hal ini meliputi dimensi bahasa, kognitif, emosional, kreativitas, dan sosial (Moeslichatoen, 1999:73). Karakteristik 
anak-anak usia dini secara umum yang dimaksud meliputi: kemampuan dalam mengintepretasikan makna, mempunyai daya perhatian serta konsentrasi yang terbatas, memahami situasi sekitar, mempunyai daya imajinasi, senang menemukan serta menciptakan sesuatu, senang bermain, senang berbicara, dan bekerja sendiri, tertarik pada aktivitas yang terkait bagi mereka, memiliki keterampilan dalam pemakaian bahasa secara terbatas akan tetapi bersifat kreatif, dapat bekerja sama dengan orang dewasa, dapat belajar dengan melakukan sesuatu, dan akan dapat belajar dengan sangat baik apabila mereka terlibat dalam berbagai aktivitas yang memiliki keterkaitan dengan diri mereka. Lebih lanjut, Asher (1996), menyebutkan bahwa faktor emosi sangat efektif dalam pembelajaran bahasa anak, artinya belajar bahasa sembari melibatkan permainan yang memungkinkan mereka bergerak dan bisa dikombinasikan dengan bernyanyi atau bercerita akan dapat mengurangi tekanan belajar bahasa seseorang. Seyogyanya keceriaan dalam diri anak (positive mood) tentu berdampak baik bagi proses belajar bahasa anak.

\subsection{Model Pembelajaran}

Sebelum dimulainya proses pembelajaran, guru sebaiknya mempersiapkan diri dan perangkat pembelajaran. Pada dasarnya pelaksanaan proses pembelajaran adalah penerapan sebuah model pembelajaran. Model pembelajaran dapat dimaknai sebagai gambaran kegiatan pembelajaran yang meliputi langkah-langkah pembelajaran yang urut. Menurut Sukirman dan
Jumhana (2006:10), pembelajaran merupakan proses interaksi lingkungan, antara guru serta unsur-unsur pembelajaran lain ataupun dengan siswa itu sendiri. Menurut Corey (Ruminiati 2007: 14), pembelajaran adalah tahapan ketika lingkungan seseorang dikelola secara sengaja dengan motif agar dapat melibatkannya dalam tingkah laku tertentu, sehingga akan menghasilkan respons terhadap situasi tertentu dalam kondisi-kondisi khusus. Hermawan, dkk. (2007: 117) menyatakan bahwa terdapat beberapa prinsip yang mesti diaplikasikan dalam pembelajaran, diantaranya: interaktif, yaitu proses interaksi baik antar guru dan siswa, siswa dengan siswa atau bahkan antara siswa dengan lingkungannya, inspiratif, yaitu proses yang bersifat inspiratif dan memungkinkan siswa melakukan suatu percobaan dan melakukan sesuatu, menyenangkan bermakna dapat dilakukan dengan cara menata ruangan yang apik dan menarik serta bervariasi, yakni dengan pemanfaatan pola dan model pembelajaran, media dan sumber-sumber yang relevan, menantang, dan motivasi merupakan aspek yang sangat penting dimana siswa mendapat dorongan yang memungkinkan siswa untuk bertindak dan melakukan sesuatu.

Berdasarkan pendapat para ahli di atas, dapat disimpulkan bahwa pembelajaran merupakan serangkaian peristiwa yang dirancang oleh guru, disusun sedemikian rupa untuk mempengaruhi dan mendukung terjadinya proses belajar siswa untuk mencapai tujuan pembelajaran. 


\subsection{Model Cooperative Learning}

Model cooperative learning merupakan suatu model pembelajaran yang memiliki tujuan untuk mewujudkan kegiatan belajar mengajar yang berpusat pada siswa (student oriented), terutama untuk mengatasi permasalahan yang ditemukan guru dalam mengaktifkan siswa (Isjoni, 2009: 9). Menurut Panitz (Suprijono, 2009: 54) istilah untuk menyebut pembelajaran berbasis sosial yaitu pembelajaran cooperative learning dankolaboratif. Kolaboratiferat kaitannya dengan sikap menghormati dan tanggung jawab pribadi, sedangkan pembelajaran cooperative learning adalah konsep yang meliputi semua jenis kerja kelompok. Artzt dan Newman (Trianto, 2009: 56) menyatakan bahwa dalam belajar cooperative, siswa belajar bersama sebagai suatu tim dalam menyelesaikan tugas-tugas kelompok untuk mencapai tujuan bersama. Jadi, setiap kelompok mempunyai tanggung jawab yang sama dalam keberhasilan kelompoknya. Dalam pembelajaran dengan menggunakan model cooperative learning, siswa bukan hanya belajar dan menerima apa yang disajikan oleh guru dalam pembelajaran, melainkan dapat belajar dari siswa lainnya serta memiliki peluang untuk membelajarkan siswa yang lain (Solihatin \& Raharjo, 2008: 2). Roger, dkk. (Huda, 2011: 29) menyatakan bahwa:

Cooperative learning is group of learning activity organized in such as a way that learning is based on the socially structured change of information between learners in group in with each leaner is held accountable for his or her own learning and is motivated to increase the learning of the others.

Berdasarkan pengertian cooperative learning tersebut, kesimpulan yang dapat diambil adalah bahwa model cooperative learning merupakan cara belajar yang memerlukan kerja sama yang baik bersama teman kelompok dan untuk mencapai tujuan pembelajaran. pembelajaran dipusatkan pada siswa

Menurut Johnson \& Jhonson (Trianto, 2009: 57), tujuan cooperative learning adalah memaksimalkan kegiatan belajar siswa dalam rangka meningkatkan prestasi akademik serta pemahaman dalam menyerap pengetahuan, baik secara individu maupun kelompok. Cooperative learning bertujuan untuk meningkatkan toleransi dan aktivitas, budaya kelas sosial, serta menerima perbedaan ras. Menurut Martati (2010:15), cooperative learning memiliki paling sedikit tiga tujuan penting, yaitu pertama cooperative learning dimaknai untuk meningkatkan aktivitas siswa melalui tugas-tugas akademis yang esensial. Tujuan kedua adalah toleransi dan penerimaan yang lebih luas terhadap orang-orang yang memiliki perbedaan dalam hal ras, kelas sosial, budaya, dan lain sebagainya. Tujuan ketiga adalah mengajarkan keterampilan untuk dapat bekerja sama dan berkolaborasi dengan siswa lain.

Berdasarkan pendapat para ahli di atas, dapat disimpulkan bahwa cooperative learning memiliki tujuan 
agar siswa dapat belajar memiliki tanggung jawab dan berkerja sama dengan baik untuk dapat mencapai tujuan pembelajaran.

\subsection{Model Pembelajaran Kooperatif tipe Talking Stick}

\subsubsection{Konsep Dasar Model Pembelajaran Kooperatif tipe Talking Stick}

Talking Stick atau yang banyak dikenal dengan istilah Talking Stick adalah sebuah metode yang pada awalnya dipergunakan oleh penduduk asli Amerika dalam kepentingan penyampaian pendapat pada suatu forum (pertemuan antar suku), sebagaimana disampaikan Carol Locust (dalam Widyatun, 2012:23) seperti berikut ini:

Talking Stick telah digunakan selama berabad-abad oleh suku-suku Indian sebagai alat menyimak secara adil dan tidak memihak. Talking Stick sering digunakan kalangan dewan untuk memutuskan siapa yang mempunyai hak berbicara. Pada saat pimpinan rapat mulai berdiskusi dan membahas masalah, ia harus memegang Talking Stick. Tongkat dapat berpindah ke orang lain jika ia mau berbicara atau menanggapinya. Dengan cara ini Talking Stick akan berpindah dari satu orang ke orang lain jika orang tersebut ingin mengemukakan pendapatnya. Jika semua telah mendapatkan giliran untuk berbicara, maka tongkat itu kemudian dikembalikan lagi ke ketua/pimpinan rapat.

Dari penjelasan di atas, dapat disimpulkan bahwa Talking Stick dipergunakan sebagai tanda bahwa seseorang memiliki hak suara (berbicara) yang diberikan secara bergantian. Talking Stick termasuk salah satu metode pembelajaran kooperatif. Menurut Kauchack dan Eggen dalam Azizah (1998:74), pembelajarankooperatifadalah strategi pembelajaran yang melibatkan siswa secaara aktif untuk bekerja secara kolaboratifdalam mencapai tujuan(Isjoni, 2010: 18). Kolaboratif dapat didefinisikan sebagai falsafah terkait tanggung jawab pribadi serta sikap menghormati sesama. Peserta didik memiliki tanggung jawab terhadap proses belajar mereka sendiri dan berusaha menggali informasi guna merespon pertanyaan-pertanyaan yang diberikan kepada mereka. Guru dalam hal ini hanya bertindak sebagai fasilitator. Metode talking stick termasuk dalam pembelajaran kooperatif karena mempunyai karakteristik yang sesuai dengan pembelajaran kooperatif, yaitu: siswa bekerja dalam kelompok-kelompok secara kooperatif untuk menyelesaikan materi belajarnya, kelompok dibentuk dengan memperhatikan kemampuan akademik siswa, yaitu tinggi, sedang dan rendah, jika memungkinkan, anggota kelompok sedapat mungkin berasal dari suku, ras, jenis kelamin, serta budaya yang berbeda, dan penghargaan yang diberikan lebih berorientasi kelompok ketimbang individu.

Implementasi metode pembelajaran ini dilakukan dengan bantuan tongkat, siswa yang mendapatkan giliran memegang tongkat wajib merespon pertanyaan dari guru setelah mereka mempelajari materi pokoknya secara tuntas. Selain untuk melatih kemampuan 
berbicara, pembelajaran ini akan menciptakan suasana yang menyenangkan serta dapat membuat siswa menjadi aktif. Adapun metode ini memberikan pengalaman belajar yang menyenangkan, meningkatkan motivasi, kepercayaan diri dan life skill yang mana pendekatan tersebut ditujukan untuk memunculkan emosi dan sikap positif belajar dalam proses belajar mengajar yang berdampak pada peningkatan kecerdasan otak. Jadi, metode Talking Stick ini adalah sebuah metode pendidikan yang dilaksanakan dengan cara memberi kebebasan kepada peserta didik untuk dapat bergerak dan bertindak dengan leluasa sejauh mungkin menghindari unsur-unsur paksaan sekaligus perintah sepanjang tidak merugikan bagi peserta didik dengan maksud untuk menumbuhkan dan mengembangkan rasa percaya diri.

\subsubsection{Model Pembelajaran Kooperatif tipe Talking Stick}

Dalam setiap kegiatan belajar, tidak terlepas dari suatu tujuan yang hendak dicapai. Pada dasarnya, pencapaian tujuan pendidikan ditentukan oleh kemampuan guru, karena faktor pendidik sangat besar peranannya. Sekiranya pendidik itu baik, maka hasil pendidikannya akan lebih baik pula. Dan sebaliknya, pendidik yang belum siap mengajar tidak akan berhasil di dalam pelaksanaan pengajaran dan pendidikan (Mansyur, 1998: 48).

Dengan demikian, seorang guru pada saat melakukan proses mengajar harus memperhatikan tujuan instruksional khusus yang ingin dicapai oleh murid. Sebab pencapaian pembelajaran khusus erat sekali kaitannya dengan tujuan pembelajaran, tujuan kurikuler, dan tujuan pendidikan nasional. Belakangan perkembangan metode pembelajaran menitik beratkan pada kemampuan murid dalam mengekspresikan seluruh potensi dan pemahamannya pada materi pelajaran. Diproyeksikan pada metode ini, dominasi guru di dalam kelas tidak ada lagi. Karenanya, metode ceramah sebagaimana dilaksanakan sejak dulu ditinggalkan. Pada metode ini, partisipasi murid di nomor satukan. Tujuannya adalah untuk memandirikan murid dalam berpikir dan memperoleh pengetahuan, serta mengolahnya hingga murid benarbenar paham terhadap materi pelajaran yang diajarkan. Perkembangan tujuan pendidikan ini berupa peningkatan pada teknik dan metode yang lebih variatif dan inovatif, danpartisipatif, yangbergunabagi perkembangan hasil belajar siswa. Dan tujuan dari inovasi pendidikan menurut Fuad Ihsan adalah untuk meningkatkan efesiensi, relevansi, kualitas dan efektifitas. Ini sesuai dengan arah inovasi pendidikan Indonesia yaitu: mengejar ketinggalan-ketinggalan yang dihasilkan oleh kemajuan-kemajuan ilmu pengetahuan dan teknologi dan mengusahakan terselenggaranya pendidikan sekolah maupun luar sekolah yang maju bagi warga negara (Fuad Ihsan, 2001: 192-193).

Maka kemudian dihadirkanlah pembelajaran kooperatif (Cooperative Learning). Konsep inti dari Cooperative Learning adalah menempatkan pengetahuan yang dipunyai siswa merupakan hasil dari aktivitas yang 
dilakukannya, bukan pengajaran yang diterima secara pasif. Menurut Isjoni, Cooperative Learning mampu mengoptimalkan cara belajar siswa menuju cara belajar yang lebih baik, sikap tolong-menolong dalam beberapa perilaku sosial. Tujuan utama dalam penerapan model belajar mengajar Cooperative Learning adalah agar peserta didik dapat belajar secara berkelompok bersama teman-temannya dengan cara saling menghargai pendapat dan memberikan kesempatan kepada orang lain untuk mengemukakan gagasannya dengan menyampaikan pendapat mereka secara kelompok (Isjoni, 2010: 21). Menurut Eggen dan Kauchak (1996: 279), pembelajaran kooperatif disusun dalam sebuah usaha untuk meningkatkan partisipasi siswa, memfasilitasi siswa dengan pengalaman sikap kepemimpinan dan membuat keputusan dalam kelompok, memberikan kesempatan pada siswa dalam rangka berinteraksi dan belajar bersama-sama siswa lainnya yang memiliki perbedaan latar belakang.

Jadi dalam pembelajaran kooperatif siswa berperan ganda yaitu sebagai siswa ataupun sebagai guru. Dengan bekerja secara kolaboratif untuk mencapai sebuah tujuan bersama, maka siswa akan mengembangkan keterampilan berhubungan dengan sesama manusia yang akan sangat bermanfaat bagi kehidupan di luar sekolah (Trianto, 2007: 42). Dengan sudut pandang di atas, dapat disimpulkan bahwa sebuah metode penguasaan haruslah sesuai dengan tujuan pendidikan di atas, yaitu partisipasi murid untuk membangun kemandirian dalam memahami materi pelajaran. Begitu pula dengan metode Talking Stick, bagaimanapun juga harus sesuai dengan tujuan pendidikan di atas. Adapun tujuan dari dirumuskannya metode Talking Stick bila dilihat dari rumusan konsep metode tersebut, yang didalamnya memperhatikan partisipasi siswa dalam memperoleh dan memahami pengetahuan serta mengembangkannya, karena metode Talking Stick adalah bagian dari salah satu metode dalam Cooperative Learnig, maka tujuan pada metode talking stick adalah untuk mewujudkan tujuan pembelajaran kooperatif (Cooperative Learning).

\subsubsection{Langkah-Langkah Model Pembelajaran Kooperatif Tipe Talking Stick}

Uno (2014: 124) menyatakan bahwa terdapat langkah-langkah dalam model pembelajaran kooperatif tipe talking stick yakni sebagai berikut: a. Guru menyiapkan sebuah tongkat b. Guru menyampaikan materi pokok yang akan dipelajari, kemudian memberikan kesempatan kepada siswa untuk membaca dan mempelajari materi pada pegangannya/ paketnya. c. Setelah selesai membaca buku dan mempelajarinya, siswa dipersilahkan untuk menutup bukunya. d. Guru mengambil tongkat dan memberikan kepada siswa, setelah itu guru memberikan pertanyaan dan siswa yang memegang tongkat tersebut harus menjawabnya. Demikian seterusnya sampai sebagian besar siswa mendapat bagian untuk menjawab setiap pertanyaan dari guru. e. Guru memberikan kesimpulan f. Evaluasi g. Penutup. 
Suprijono (2009: 109-110) menyatakan bahwa terdapat langkahlangkah dalam pembelajaran kooperatif tipe talking stick yakni sebagai berikut: a. Guru membentuk kelompok yang terdiri atas 4 orang. b. Guru menyiapkan sebuah tongkat yang panjangnya 20 cm. c. Guru menyampaikan materi pokok yang akan dipelajari, kemudian memberi kesempatan para kelompok untuk membaca dan mempelajari materi pelajaran. d. Siswa berdiskusi membahas masalah yang terdapat di dalam wacana. e. Setelah kelompok selesai membaca materi pelajaran dan mempelajari isinya, guru mempersilahkan anggota kelompok untuk menutup isi bacaan. f. Guru mengambil tongkat dan memberikan kepada salah satu anggota kelompok, setelah itu guru memberi pertanyaan dan anggota kelompok yang memegang tongkat tersebut harus menjawabnya, demikian seterusnya sampai sebagian besar siswa mendapat bagian untuk menjawab setiap pertanyaan dari guru. g. Siswa lain boleh membantu menjawab pertanyaan jika anggota kelompoknya tidak bisa menjawab pertanyaan. h. Ketika tongkat bergulir dari kelompok ke kelompok lainnya sebaiknya diiringi musik atau lagu. i. Guru melakukan evaluasi/penilaian, baik secara kelompok maupun individu. j. Guru memberi ulasan terhadap seluruh jawaban siswa, selanjutnya bersama-sama siswa merumuskan kesimpulan. k. Guru menutup pembelajaran.

\subsubsection{Keuntungan Model Pembelajaran Kooperatif Tipe Talking Stick}

Model Talking Stick memiliki banyak kelebihan dalam proses belajar mengajar. Menurut Kagan dan Kagan (2009: 15), Talking Stick memiliki banyak kelebihan, diantaranya adalah sebagai berikut: (1) Struktur berbicara yang menyamakan komunikasi, memberi setiap siswa kesempatan untuk menggunakan dan mengembangkan keterampilan berbahasa; (2) Memberikan setiap siswa jumlah waktu yang sama; (3) Siswa memiliki forum untuk mempertajam keterampilan bahasa pemula mereka. Senada dengan hal di atas, Aini (2010: 34) menyatakan bahwa model talking stick memiliki keuntungan tersendiri. Model ini memberikan keuntungan untuk menarik perhatian siswa, sehingga mereka lebih serius dalam belajar. Kagan (2009) menjelaskan keuntungan model talking stick sebagai berikut: (1) Tetap waspada. (2) Membantu guru menyadari jika siswa mendengarkan dan memahami atau tidak. (3) Membantu guru mencari tahu apa yang sudah mereka ketahui. (4) Guru berbicara tidak terlalu banyak dan siswa berbicara lebih banyak.

\section{SIMPULAN}

Mampu berkomunikasi secara lisan dalam bahasa Inggris telah menjadi sesuatu yang penting. Dengan menguasai keterampilan berbicara, orang dapat melakukan percakapan dengan orang lain, berbagi ide, dan bertukar informasi dengan orang lain di seluruh dunia. Akan lebih mudah bagi kita untuk berkomunikasi 
dengan orang-orang di luar negeri, terutama mereka yang menggunakan bahasa Inggris sebagai bahasa mereka. Dalam mengajar berbicara, guru bahasa Inggris harus kreatif untuk merancang banyak kegiatan komunikasi di kelas yang mendorong dan memotivasi siswa untuk menggunakan bahasa secara aktif dan produktif. Dengan kata lain, guru bertanggung jawab atas situasi di mana siswa dapat berkomunikasi secara lisan dengan teman sekelas mereka. Untuk membuat siswa lebih aktif, diperlukan teknik yang lebih mudah bagi siswa. Pada prinsipnya, model talking stick adalah model pembelajaran interaktif karena menekankan pada keterlibatan aktif anak selama proses pembelajaran. Untuk meningkatkan aktivitas belajar anak, guru menggunakan media tongkat sebagai alat bantu dalam pelaksanaan talking stick. Dengan demikian, pembelajaran dengan metode talking stick berorientasi murni pada aktivitas individu anak yang dilakukan dalam bentuk permainan. Sehingga, model talking stick dapat diterapkan dalam pembelajaran sehari hari pada mata pelajaran manapun. Diharapkan, anak yang telah mengikuti proses pembelajaran dengan menggunakan model talking stick ini dapat memahami banyak pengetahuan dan keterampilan. Anak menjadi termotivasi untuk belajar lebih giat, kegiatan belajar menjadi menyenangkan dan tidak membosankan. Pengalaman belajar yang menyenangkan dapat diberikan oleh model pembelajaran ini, selain daripada itu juga dapat meningkatkan motivasi, kepercayaan diri dan life skill. Model talking stick ditujukan untuk memunculkan emosi dan sikap positif belajar dalam proses belajar mengajar yang berdampak pada peningkatan kecerdasan otak.

\section{DAFTAR PUSTAKA}

Aini, Irfatul. 2010. Application of Innovative Instruction Model by Means of the Talking Stick Method to Improve the Students Learning Activity on the Integrated Social Studies Subject Matter of VIIth Grade of the State Junior High School 1 of Singosari Malang. Minithesis.

Asher. 1966. Total Physical ResponseTPR. [Online]. Tersedia di: http://www2.vobs.at/ludescher/ Ludescher/LAcquisition/total_ physical_respons.

Azizah, Noor. 2007. Keefektifan Penggunaan Model Pembelajaran

Kooperatif Tipe Numbered Head Together dengan Pemanfaatan LKS (Lembar Kerja Siswa) Siswa Kelas VIII Semester 2 SMP N 6 Semarang.

Skripsi. Tidak Diterbitkan.

Departemen Pendidikan dan Kebudayaan.

2001. Kamus Besar Bahasa

Indonesia. Jakarta: Balai Pustaka.

Eggen, P.D. and Kauchak. D.P. 1996. Learning and Teaching. 2 nd ed. Needdham. Height, Massachussets:

Allyn and Bacon.

Fuad Ihsan. 2001. Dasar-Dasar Kependidikan. Jakarta: Rineka Cipta. 
Helmes, D. B., \& Turner, J. S. 1995. Human Development (5th ed.). New York: McGraw-Hill.

Hermawan, H. 2007. Media Pembelajaran $S D$. Bandung: UPI Press.

Huda, Miftahul. 2011. Cooperative Learning. Yogyakarta: Pustaka Pelajar.

Huda, Miftahul. 2014. Model-Model Pembelajaran. Yogyakarta: Pustaka Pelajar.

Hurlock, Elizabeth B. 1978. Perkembangan Anak. Jakarta: Erlangga.

Isjoni. 2009. Cooperative Learning (Efektivitas Pembelajaran Kelompok). Bandung: Alfabeta.

Kagan, Spencer. Kagan, Miguel. 2009. Kagan Cooperative Learning. San Clemente: Kagan Publishing.

Kurniasih dan Sani. 2015. Model Pembelajaran. Yogyakarta: Kata Pena.

Mansyur. 1998. Strategi Belajar Mengajar, PPG 12170 / 2 SKS / Modul 1-6. Jakarta: Dirjen Pem. Kelembagaan Agama Islam dan Universitas. Terbuka.

Martati, Badruli. 2010. Metodologi Pembelajaran Pendidikan Ke warga ne gar a a $n$ Strategi Penanaman Nilai. Ganesindo. Bandung.
Moeslichatoen. 1999. Metode Pengajaran di Taman Kanak-Kanak. Jakarta: Rineka Cipta.

Ruminiati. 2007. Pengembangan Pendidikan. Direktorat Jendral Pendidikan Tinggi Departemen Pendidikan Nasional, Jakarta.

Solihatin, dan Raharjo. 2008. Cooperative Learning. Jakarta: PT. Bumi Aksara.

Sukirman, D., Jumhana N. 2006. Perencanaan Pembelajaran. Bandung: UPI Press.

Sunarto, H. A. 2008. Perkembangan Peserta Didik. Jakarta: Rineka Cipta.

Suprijono, Agus. 2009. Cooperative Learning, Teori \& Aplikasi PAIKEM. Surabaya: Pustaka Pelajar

Suprijono, Agus. 2015. Cooperative Learning. Yogyakarta: Pustaka Pelajar.

Trianto. 2009. Mendesain Model Pembelajaran Inovatif Progresif. Jakarta: Kencana Prenada Group.

Turner, J.S \& Helms, D.B. 1995. Life Span Development. Fifth Edition. Tokyo: Harcourt Brace College Publishers. Widyatun, Diah. 2012. Model Pembelajaran Kooperatif Tipe Two Stay Two Stray (TSTS). http://jurnalbidandiah. blogspot.com/. Diakses pada tanggal 27 Maret 2018. 